\title{
EXPERIENCE IN BRAZIL WITH THE USE OF AVAILABLE SHISTOSOMICIDES IN MASS TREATMENT CAMPAIGNS
}

\author{
Aluizio Prata *
}

\section{INTRODUCTION}

Mass treatment for schistosomiasis ideally refers to the universal treatment of whole populations living in endemic areas, however as non toxic drugs are not yet available for schistosomiasis, treatment should not apply to all members of such communities as with malaria. Vianna Martins ${ }^{15}$ defines it as being a simultaneous or almost simultaneous treatment of a. large number of people representative of a population. Although the lack of single dose therapy in the past made it difficult to establish mass treatment for schistosomiasis, programmes have been carried out which could be considered as mass treatments, reaching large members of people infected by Schistosoma in a well defined population.

\section{Programes of Mass Treatment in Brazil}

Antimony compounds. Heraldo Maciel ${ }^{14}$ first used antimony compounds in Brazil for mass treatment of schistosomiasis. He treated 1.063 sailors ( $9 \%$ of the Brazilian Navy) in the period of 1923 - 1928. Tartar emetic was used in a total dose of $0.95 \mathrm{~g}$ intravenously administered over a period of ten days. He claimed $92 \%$ success in therapy.
In 1943, treatment of schistosomiasis became compulsory in the village of Catende in the state of Pemambuco ${ }^{10}$. Seven thousand people were examined and 4,171 were found to have Schistosoma eggs in their stools. In the period of 1943 to $1947,3,539$ people started treatment of which 3,334 completed it. The drug used was tartar emetic. Only one death was reported. Although this form of treatment was not widely accepted in the period of 1949 to 1952, 582 more people were treated. The efficacy of this therapy was assessed by stool examinations in the three months following therapy, and sixty four per cent of treated patients were found to have negative stools.

From 1951 onwards, Sette ${ }^{18}$ set up a long term follow-up to assess treatment of schistosomiasis in Catende. He reviewed 1,094 treated patients and compared them with a similar group of non treated patients; he found that $40 \%$ of the treated group still passed eggs in stools as compared to $66 \%$ in the control group. Liver function tests were better in the treated group, and only $1.7 \%$ of patients progressed to the hepatosplenic form as compared to $9 \%$ in the non treated group. Since histopathological examinations had been carried out as a routine in those who died in the area before and after introdution of compulsory therapy for schisto- 
somiasis, it was possible to analyse the prevalence of schistosomotic lesions in the population, It was found that such lesions were prevalent in the order of $16.5 \%$ before treatment and $11.5 \%$ after treatment. As far as hepatic fibrosis is concerned, its prevalence was $5.4 \%$ before treatment and $1.3 \%$ after treatment Althought his data are very important, his control groups were too small (sometimes only 25 cases) to enable us to draw any definite conclusions. It is noteworthy that in the village of Catende, together with the compulsory treatment for schistosomiasis, a hygiene education campaign was set up and moluscicides were introduced, although these measures were not continued ${ }^{18}$.

After the discovery of an endemic area in the town of Araxá, State of Minas Gerais, all those passing Schistosoma eggs in stools were treated using neo-antimosan. A year later, Rodrigues da Silva ${ }^{19}$ showed that $85 \%$ of treated patients were still passing eggs in their stools. Such a high prevalence of positive stool examinations could well be explained however by either re-infection or failure in therapy. The same high prevalence of positive stool examinations after treatment was found in the village of Redenção, in the state of Ceará. Rodrigues da Silva commenting on this says that re-infection may well explain the high prevalence of positive stool examinations in patients treated in Redenção, whereas in Araxá failure in therapy could well be the case ${ }^{21}$. Neo-antimosan however was succesfully used in Fordlandia, in the state of Pará. One hundred and thirty patients out of a population of 2.000 were treated in the period of 1954 to 1956 and in 1962 only 19 patients were found to pass schistosoma eggs in their stools. These were treated ${ }^{9}$, and now Fordlandia is no longer an endemic area.

By 1956, 15,000 patients in the Northeast of Brazil had been treated by the Ministry of Health through a national campaign ${ }^{20}$; 10,000 more were treated in $1957^{22}$. The drugs used were: 1) Neo-antimosan in a total dose of $1 \mathrm{ml}\left(8.5 \mathrm{mg} \mathrm{Sb}{ }^{+++}\right)$per $\mathrm{kg}$. b.w. intramuscularly over a period of 12 days; 2) Antimony dimercaptosuccinate in a dose of $40 \mathrm{mg} / \mathrm{kg}$.b.w. in tramuscularly over six days; 3) Sodium antimonyl gluconate in a dose of $17 \mathrm{mg} / \mathrm{kg} . \mathrm{b} . \mathrm{w}$. intravenously over six days. About $80 \%$ of patients completed treatment and only one death was reported ${ }^{20}$. The cure rate was assessed by four stool examinations in the four months following treatment and was found to be $70 \%{ }^{16}$. This treament was carried out by local clinics, one of them (Itaporanga) had
6,000 patients. Rodrigues da Silva ${ }^{22}$ analysing the results of this campaign stressed that the elderly group of treated patients presented higher rates of negative stools. In Itaporanga the rate of positive stool examinations dropped from $78.5 \%$ to $59.5 \%$.

In the period 1962 to $1971,82,276$ more patients were treated by the Ministry of Health; this figure does not include patients treated by health services in different States of the country ${ }^{9}$. The results however of this campaign have not yet been analised.

Freitas ${ }^{9}$ criticized governmental programmes for the control and treatment of schistosomiasis in Brazil - mass treatment included-chiefly because of lack of continuity.

Kloetzel ${ }^{13}$ treated 112 youngsters with an antimonial drug in the village of Gameleira, in the State of Pernambuco. Gameleira has 5,000 inhabitants and is located in an endemic area. $A$ $90 \%$ decrease in stool egg excretion was found after one year of treatment.

Following Davis' concept of mass chemotherapy specifc to an age group, Prata $e t a l^{7}$, from 1952 to 1973 treated 1,679 navy trainees in the state of Bahia. All those who joined the Navy during that time were investigated by stool examination and rectal biopsy, and those who were found to be positive were allocated to different schemes of teatment. More than 20 schedules were used and the cure rate was largely dependant on the kind of scheme used.

Hycanthone - The great advantage of hycanthone therapy has been the possibility of a single dose therapy, making it suitable for mass treatment $^{8}$.

$\mathrm{Piza}^{17}$, in the State of São Paulo, has the largest series of treated patients with hycanthone, and so far 61,461 patients have been treated. The initial schedule recommended by the campaign against schistosomiasis in this state was $3 \mathrm{mg} / \mathrm{kg} . \mathrm{b} . \mathrm{w}$. but later reduced to $2.5 \mathrm{mg} / \mathrm{kg}$ b.w. Although this campaign is still in progress, its results have not yet been assessed. A complicating factor is that internal immigration is responsible for the ever increasing extent of endemic area in the state of São Paulo. According to the selection and guidance immigrant service, at least 36,000 new schistosomiasis patients moved to São Paulo in the period of 1973-1974.

In the period of 1973-1975, 25,798 patients were treated with hycanthone by the Ministry of Health. Seventy five per cent of these patients were from the States of Paraiba, Espírito Santo, Rio de Janeiro and Paraná. 
There are however no available data on the results of this treatment.

Bina and Prata $^{3}$ treated 211 schistosomatic patients living in Varzea Nova, an area where transmission of the disease was low. The age range was 2-74 years and 15 patients had the hepatosplenic form of the disease, while 196 had the hepato-intestinal form. Hycanthone was used in a single dose of $2.5 \mathrm{mg} / \mathrm{kg}$. b.w. intramuscularly. Only pregnant women and two other patients with contraindications were not treated. Side effects were nausea, vomiting, anorexia, dizziness, headache, drowsiness, sleepness and pain at the site of the injection. Howeyer they were only mild or moderate and not lasting more than 24 hours. In only 4 patients were positive stools found in five examinations after five months of treatment, and in only one after 16 months.

Hycanthone, in a single intramuscular dose of $3.3 \mathrm{mg} / \mathrm{kg}$ of body weight, was used to treat 597 persons in the endemic village of Canabrava in the state of Bahia ${ }^{4}$. Eighty three per cent of the total population was treated, leaving only $7 \%$ of patients with Schistosomiasis not treated. Treatment was given to the whole group over two days, the drug being well tolerated with the frequency and intensity of toxic reactions and side effects similar to those observed in Varzea Nova. After five stool examinations 14 months later, 152 patients (25.5\%) were still passing eggs in stools. Ninety two positive patients were then re-treated with hycanthone using the same schedule. There was one death probably caused by toxic hepatitis. The first stool examination after the second treatment was negative in $77 \%$ of the patients, in comparison with the $93,7 \%$ after the first one. This suggests the possibility of acquired resistance. The final stool examination 38 months after the initial treatment, showed $19 \%$ of patients passing eggs. This percentage is considerably better than the pre-treatment value of $46.3 \%$, and applies for all ages (see graph).

Similar results were obtained by Aguirre et al in the states of Rio de Janeiro and Rio Grande do Norte ${ }^{1}$.

Katz et $a /^{11}$ treated 760 patients in the village of Baldim in the state of Minas Gerais. Only 16 pregnant women and another 22 patients with serious concurring disease were not treated. Hycanthone was used in a single dose of $2.5 \mathrm{mg} / \mathrm{kg}$ b.w. intramuscularly. Side effects were nausea, vomiting, anorexia, muscle pain, headache, dizziness, and tenderness at the site of injection, but they were mild to modera- te and disappeared in 24 hours. The percentage cure after three negative stool examinations was $95.6 \%$. Katz stressed the fact that he had already treated more than 9,000 patients without fatality or even jaundice.

Therefore in the past five years more than 100,000 people have been treated as part of controlled therapeutic programmes, and the manufacturers of hycanthone claimed that by June 1975, 433,018 patients had been treated in Brazil.

Oxamniquine - Bina and Prata ${ }^{5}$ treated 75 children aged from 3 to 12 years in Taquarendi in the State of Bahia. This is an endemic area but where transmission has been prevented.

An oral suspension of oxamniquine was used in single dose of $15-25 \mathrm{mg} / \mathrm{kg}$ b.w. Twenty one per cent of the patients had one or more of the following side effects: dizziness, drowsiness, nausea and occasionally vomiting, but they disappeared spontaneously in one to two hours. The cure rate was $88 \%$. Another group of 313 patients with the hepato-splenic form of schistosomiasis was treated by the same authors in Mirangaba. (Bahia), where there is also no transmission of schistosomiasis. Oxam. niquine was used in capsule form for adults in a dose $12,5-15 \mathrm{mg} / \mathrm{kg} \mathrm{b.w.}$, and in suspension form for children in a dose of $20 \mathrm{mg} / \mathrm{kg} \mathrm{b.w}$. Fifty six per cent of patients had one or more of the following symptoms: dizziness, drowsiness, headache, nausea $(7.34 \%)$, vomiting $(2.85 \%)$. These side effects disappeared in the following two hours after treatment. The cure rate was assessed by five stool examinations in the six months following treatment, and $84 \%$ of patients were found to have negative stool examinations.

The same authors treated 286 patients in the endemic area of Boa Esperança in the state of Bahia. The number of patients treated represented $87.7 \%$ of the whole population and $11.4 \%$ of them had a severe form of the disease. Oxamniquine dose was the same and side effects were similar to previously reported in Mirangaba.

Coura et $a l^{6}$ treated 504 patients in two different viliages in the Rio Doce basin in the State of Minas Gerais. They were 310 patients in São Geraldo, comprising the whole population, and 194 patients in Itanhomi (25\% of the population). Oxamniquine was used in a singgle dose of $12.5-18 \mathrm{mg} / \mathrm{kg} \mathrm{b.w}$. Side effects were dizziness $(13.6 \%)$, nausea $(2.3 \%)$, headache $(2.3 \%)$, vomiting $(1.6 \%)$, abdominal pain $(0.9 \%)$. Two patients had pshychiatric distur- 
PREVALENCE OF SCHISTOSOMIASIS MEASURED BY

THE PRESENCE OF EGGS IN STOOLS, BEFORE AND AFTER

TREATMENT, ACCORDING TO AGE GROUPS

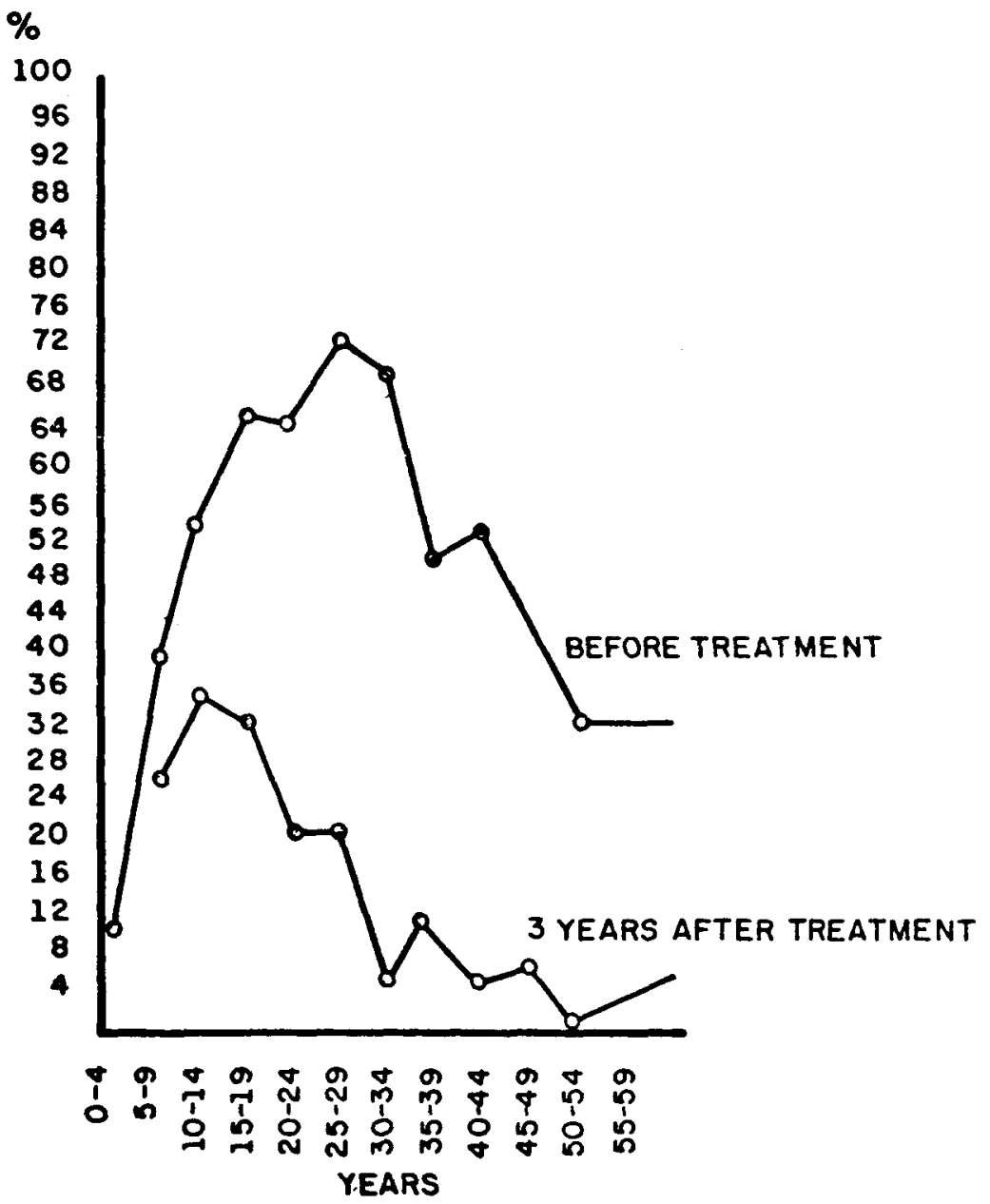


bances: one became aggressive and the other presented perceptual disturbances. Apart from these two patients, side effects were mild and transient not requiring medication. Evaluation is still in progress, but so far $87.2 \%$ of patients show negative stools.

Katz and Zicker ${ }^{12}$, using a single oral dose of oxamniquine of $20 \mathrm{mg} / \mathrm{kg} \mathrm{b.w}$. for children and $15 \mathrm{mg} / \mathrm{b} . \mathrm{w}$. for adults, treated 220 patients in the village of Peri Peri in the state of Minas Gerais. Side effects were mild and the authors recommend the drug for the treatment of communities. The cure rates assessed by 2-4 stools examinations four months after therapy were found to be $65,5 \%$ for children and $82.4 \%$ for adults.

The manufacturers stated that by June 1975 oxamniquine had been given to more than 100,000 patients without fatality or even jaundice.

In conclusion, apart from the two cases of neuropshychiatric disturbances reported by Coura et al, no serious complication has been observed with oxamniquine.

\section{COMMENTS}

Mass treatment of schistosomiasis in the past was done cautiously with antimony compounds and large numbers of patients were treated by the Ministry of Health through health clinics. Toxicity of antimony cmpounds, long term therapy, difficulty in injecting the drug and the possibility of re-infection hindered the pilot projects. Furthermore patients co-operated poorly and the mass treatment in the village of Catende left doubts as to the applicability of this kind of treatment in Brazil.

This situation was not altered by the use of Niridazole once it was found that large numbers of patients-particularly those with hepatosple- nomegaly-complained of various neurological symptons.

During the last six years however, the introduction of single dose therapy has made easier mass treatment of schistosomiasis. Hycanthone has been used in various pilot projects and at presente two very large compaigns are still in progress. Unfortunately with the treatment of more cases reports of severe toxic hepatitis have appeared ${ }^{2}$ and the possibility of resistance after the first dose, together with accusations of teratogenic, carcinogenic and mutagenic effects - although not substantiated $^{24}$, - have reduced the use of hycan thone as a drug for mass treatment. However it has been used in this way in Brazil with more than 100,000 patients.

Oxamniquine in oral form raised optimism as a suitable drug for mass treatment of schistosomiasis, but so far it has only been used in pilot projects.

Perhaps we are not far away from introducing mass treatment for schistosomiasis as for malaria. This is not possible with hycanthone and as yet we do not know whether it will be possible with oxamniquine; we may have to await the emergence of a new drug.

It is evident that mass treatment of schistosomiasis is the best form of treatment in a non endemic area, as was seen in Fordlandia where the disease was eradicated by specific treatment, and in Varzea Nova where it was controled.

The Brazilian experience shows that during the long term, treatment may decrease the prevalence of the disease even in endemic areas - although it is difficult to assess it in terms of the general control of the disease.

It appears that treatment of schistosomiasis prevents the appearance of serious forms of the disease.

\section{REFERENCES}

1. AGUIRRE, G.H., SANDIA, O.G., OLIVEIRA, P.A., TAVARES, M.D. \& VALENTE, Fo P. Controle experimental da esquistossomose mansoni pela terapêutica. Rev. Bras. Mal. Doenças Trop. 24:65-94, 1972.

2. ANDRADE, Z. Hycanthone and the liver. Afro-Brazilian Symposium on Schistosomiasis, pag. 67-70. Brasllia. 1974.

3. BINA, J.C. \& PRATA, A. Hycan thone no tratamento da esquistossomose em uma área rural com baixo índice de transmissão da doença. Gaz. Med. Bahia. 70:127-130, 1970.

4. BINA, J.C. \& PRATA, A. An attempt to control schistosomiasis mansoni in an endemic area by the use of Hycanthone as chemotherapeutic agent. Rev. Soc. Bras. Med. Trop. 8:217-222, 1974.

5. BINA, J.C. \& PRATA, A. Tratamento da esquistossomose com Oxamniquine (xaro- 
pel em crianças. Rev. Soc. Bras. Med. Trop. (in press).

6. COURA, J.R., ARGENTO, C.A., MAGALHÄES, P. \& LEWIS, F.M. Field trials with oral oxamniquine in a single dose treatment of schistosomiasis mansoni. Personal communication. 1975.

7. DAVIS, A. Mass Chemotherapy: Problems and Prospects. Proceedings of a Symposium on the Future of Schistosomiasis Control. New Orleans, 1972.

8. FIGUEIREDO, J.F.M. \& PRATA, A. Eficácia do Hycanthone no tratamento da esquistossomose mansoni. Gaz. Med. Bahia. 69:16-19, jan./abr. 1969.

9. FREITAS, C.A. Situação atual da esquistossomose no Brasil. 24:3-63, 1972.

10. JANSEN, G. Profilaxia experimental da esquistossomose de Manson. Mem. Inst. Oswaldo Cruz. 44:549-578, 1946.

11. KATZ, N., ANTUNES, C.M.F., ANDRADE, R.M. \& COELHO, P.M.Z. An attempt to control schistosomiasis mansoni in an endermic area by combining clinical treatment and molluscicide application. J. Parasit (Section II) 55:434, 1970.

12. KATZ, N. \& ZICKER, F. Personal communication. 1975.

13. KLOETZEL, K. Sobre a conveniência da quimioterapia da esquistossomose em população em contínuo contato com os focos. Rev. Inst. Med. Trop. São Paulo. 5:106-110, 1963.

14. MACIEL, H. O tratamento da eschistosomose intestinal no Hospital da Marinha. Sci. Méd. 7:20-4, 1929.

15. MARTINS, A.V. Plano de tratamento em massa. In Esquistossomose mansoni no Brasil. São Paulo. 1952.
16. PINOTTI, M. O estado atual e o futuro do combate à esquistossomose no Brasil. Sim. pósio sobre esquistossomose. Edited by $A$. Prata \& E. Aboim. Salvador. Arq. Bras. Med. Naval. 18:5105-30, 1957.

17. PIZA, J.T. O uso de esquistossomicidas em Campanhas de Saúde Pública. Congresso Brasileiro Hepatologia. Belo Horizonte, 1975.

18. SETTE, H. O tratamento da esquistossomose mansoni à luz da Patologia hepática. Recife, Fac. de Medicina, 1953. 220 p. (Thesis).

19. SILVA, J.R. Quimioterapia por via oral na esquistossomose mansoni. Rio de Janeiro, Fac. Ciências Médicas. 220 p. 1955 (Thesis).

20. SILVA, J.R. Esquistossomose intestinal. Simpósio sobre esquistossomose: epidemiologia, diagnóstico, tratamento. Rio de Janeiro, Graf. Muniz. 1957. p. 43-60.

21. SILVA, J.R. Estado atual e perspectivas da quimioterapia especifica na esquistossomose mansoni. J. Bras. Med. 3:1-14, jul. 1960.

22. SILVA, J.R. Avaliação dos resultados da terapêutica espec/fica da esquistossomose mansoni em uma campanha de Saúde Pública no Brasil. In: Proceedings of the International Congress on Tropical Medicine and Malaria, 6th, Lisboa. 1958. 2:89-100.

23. SILVA, J.R. Valor e importância do tratamento especifico da esquistossomose mansoni, no campo da profilaxia. Rev. Bras. Med. 14:524-6, 1957.

24. WHO. Report of a WHO Consultant Group on Hycanthone. Geneva, 26-29 June. 1972. 